\title{
A Retrospective Look At The Sarbanes-Oxley Act Of 2002- Has It Accomplished Its Original Purpose?
}

Anthony Basile Ph.D., CPA, CVA, CFE, Hofstra University, USA

Sheila Handy, Ph.D., CPA, East Stroudsburg University, USA

Felisha N. Fret, M.S., Hofstra University, USA

\begin{abstract}
As a result of notable frauds including Enron, WorldCom and Waste Management, the United States Congress enacted the Sarbanes-Oxley Act of 2002 (SOX). The Act would forever change the accounting profession. After a little more than a decade, publicly traded companies have been able to create and implement policies and procedures to ensure compliance with the Act, specifically the provisions set forth in Section 404. Since all public companies have implemented SOX compliance together with other regulations imposed by the Internal Revenue Service and other regulatory agencies into their normal reporting routines, management of these companies have realized further benefits associated with SOX compliance. Because of these reported benefits many private companies have begun to voluntarily implement SOX-like policies and procedures into their own internal framework. This paper will discuss the perceptions of the enactment and implementation of the Act, the associated benefits derived from SOX compliance and reasons why private companies have begun voluntarily adopting SOX-like policies, procedures and strategies.
\end{abstract}

Keywords: SOX; SOX Compliance; SOX Policies; SOX Implementation

\section{INTRODUCTION}

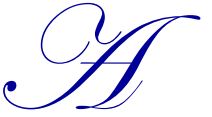

little over a decade ago, the accounting profession experienced profound changes as a result of notable fraudulent scandals such as WorldCom, Tyco, Waste Management, and Enron. With the development of a widespread trend of fraud and corporate asset misappropriation as well as the roles of the associated accounting professionals, Congress responded by enacting the Sarbanes-Oxley Act of 2002. This legislation brought unprecedented oversight and regulation to a profession that once prided itself on being one of the only self-regulated professions.

The Sarbanes-Oxley Act of 2002 would forever change the accounting profession. Specifically, it created governmental oversight for auditors of public companies, while still allowing the accounting profession to continue to be self-regulating on audits of non public entities, therefore creating separate auditing standards and regulation requirements for audits of public and non-nonpublic entities. While the legislation stipulated numerous provisions for both companies and auditors to adhere to, the one provision that received the majority of the public's focus, controversy and concern was Section 404. Public companies as well as their auditors, fell under the jurisdiction of this legislation and would face an unprecedented expansion of responsibilities and requirements. These new responsibilities include, but are not limited to:

(1) The public company must create, implement and document internal controls,

(2) Management of public companies must assess and report weaknesses of such internal controls,

(3) Auditors of public companies must report on management's assessment of internal controls, and

(4) Auditors of public companies are responsible for conducting an independent assessment and report on the company's internal controls. 
In addition to the aforementioned responsibilities, the Sarbanes-Oxley Act also introduced an expansion of corporate governance, including auditor independence, restricting the contracting of firms for auditing and consulting services, as well as the personal certification of a firm's financial statements by its respective Chief Financial Officer and Chief Executive Officer. ${ }^{1}$

It is no surprise that the enactment of the Sarbanes-Oxley Act of 2002 (henceforth referred to as "SOX" or "the Act") led to much controversy over compliance with its multiple provisions, specifically those imposed by Section 404 . Such criticisms were primarily attributed to the significant compliance costs that public companies would incur as a result of the absence of clear implementation guidance.

After more than a decade of gaining experience with SOX implementation through trial and error, publicly traded companies have now grown more familiar and somewhat more comfortable with its provisions. Since all public companies have implemented SOX provisions together with regulations imposed by the Internal Revenue Service and other agencies into their normal reporting routines, management of these companies have realized further benefits associated with SOX compliance. Because of these reported benefits many private companies have begun to voluntarily implement SOX-like policies and procedures into their own internal framework.

This paper will discuss:

(1) The Positive And Negative Perceptions Of The Enactment And Implementation Of The Sarbanes-Oxley Act Of 2002,

(2) The Associated Benefits Derived From SOX Compliance, And

(3) Reasons why private companies have begun voluntarily adopting SOX-like policies, procedures and strategies.

\section{PERCEPTIONS OF THE SARBANES-OXLEY ACT OF 2002}

The US Congress enacted the Sarbanes-Oxley Act of 2002 in response to the declining confidence of investors as a result of notable fraud scandals, such as those perpetrated by Enron, WorldCom, and Waste Management. While Congress viewed such legislation as a step in the direction of improving confidence in the marketplace as well providing, in their opinion, much needed oversight, many companies greeted the Act with great concern, criticism, and disdain.

Provisions of Section 404 significantly increased the attention to, reliance on, and testing and documentation of internal controls, quickly making the legislation unpopular. Public companies have always been responsible for the establishment and maintenance of an adequate system of internal control pursuant to the Foreign Corrupt Practices Act of 1977, but SOX amplified the concentration on internal control compliance throughout the company and extended responsibility to auditors. The increased testing and evaluation of internal controls required of both the company and external auditors has created an enormous compliance burden. A costly dilemma faced by the companies subject to SOX was that any evaluation or documentation of internal control required to comply with the Act had to be conducted by another independent CPA firm as the Act prohibited auditors from providing any consulting to the companies they audited. Therefore public companies found during the initial documentation and implementation phase that they had to absorb the fees of two, usually very large, CPA firms. The high compliance costs along with the lack of implementation guidance created resistance among publicly traded companies that were required to comply with provisions of the Act.

A 2005 survey conducted by Foley \& Lardner, LLP revealed that the average cost associated with being a publicly traded company increased by $233 \%$ for companies with less than $\$ 1$ billion in revenue. Additionally, AMR Research reported that companies spent approximately \$6 billion a year in compliance costs in 2005 and 2006. These increases in costs may explain why many public companies began privatizing and voluntarily deregistering their securities with the Securities \& Exchange Commission (SEC). Approximately 920 companies deregistered

${ }^{1}$ Dalton, D. R., \& Dalton, C. M. (2005). Sarbanes-Oxley legislation and the private company: If not a marriage, then certainly an engagement. Journal of Business Strategy, 26(2), 7-8. 
between 1998 through 2004, with 450 companies doing so subsequent to the implementation of SOX (during 20032004). ${ }^{2}$

Since the initial registration, companies had to respond to the new regulation by expanding staff, technology, consulting costs and training to meet with the requirements of documentation and assessment of internal controls.

Over time, however, many companies have become accustomed to complying with the provisions of the Act and overall perception has become more positive. In the first quarter of early 2010, Protiviti conducted a Sarbanes-Oxley Compliance survey to assess the state of SOX compliance, its associated costs and benefits, as well as its perceived value. Approximately 400 US executives and professionals, including C-level executives, corporate compliance officers and audit professionals whose companyies' gross annual revenues ranged from less than $\$ 100$ million to greater than $\$ 20$ billion completed the survey. Approximately $68 \%$ were employed by companies in the fourth year or later of SOX compliance. ${ }^{3}$ Approximately $70 \%$ of respondents stated that the associated benefits of SOX compliance far outweighed the compliance costs, whereas only $39 \%$ of those respondents in their first year of compliance expressed that sentiment. ${ }^{4}$ As managers became more familiar with the requirements, an appreciation for the benefits that resulted began to emerge.

The survey verified that over time and experience with SOX compliance, many companies experienced significant decreases in associated compliance costs. Respondents in their fourth year or later of compliance reported a $50 \%$ reduction (on average) in compliance costs. Further, $87 \%$ of respondents believed that SOX compliance provided numerous benefits. ${ }^{5}$ This high percentage validates that managers of companies that employ SOX procedures and policies will derive significant benefits as well as opportunities to improve their organizations. However, according to Jim DeLoach, managing director of Provitivi and lead SOX practice leader, in order to realize the full potential and benefits associated with SOX, companies "must view their efforts as an ongoing activity that should mature and improve over time."

With the $10^{\text {th }}$ anniversary of Sarbanes-Oxley's enactment, Protiviti surveyed approximately 600 internal audit, compliance and financial executives to determine how their perceptions of the legislation have progressed, specifically addressing issues related to the associated costs and benefits attributable to realizing a stronger internal control environment and achieving improved efficiency in operations . ${ }^{7}$ Brian Christensen, Executive Vice President of Protiviti's Global Internal Audit group, stated that $70 \%$ of respondents reported improvements in their internal control over financial reporting systems since compliance with Section 404 of the Act became a requirement. ${ }^{8}$

\footnotetext{
${ }^{2}$ Bradford, M. \& Brazel, J. (2007). Flirting with SOX 404: Are private companies interested in a relationship?. Strategic Finance, 89(3), 48-53.

${ }^{3}$ (2010). New research from Protiviti finds majority of executives experienced with Sarbanes-Oxley compliance believe benefits outweigh the costs; new sox survey uncovers spending trends, attitudes, outlooks and more. PR Newswire.

${ }_{5}^{4}$ Ibid

${ }^{5}$ Ibid

${ }^{6}$ Ibid

${ }^{7}$ Christensen, B., \& DeLoach, J. (2012). Sarbanes-Oxley: What do financial executives really think? Financial Executive, $28(5), 58-61$.

${ }^{8}$ (2012). Firms highlight reporting benefits of Sarbanes-Oxley. Financial Management.
} 
Based upon the results of the study, it appears that companies are still learning and diligently working toward improving the quality of internal control processes as well as the effectiveness and efficiency of compliance processes. ${ }^{9}$ According to Christensen \& DeLoach (2012), following are the top three benefits executives expect to experience in the upcoming fiscal years:

- "Enhanced Understanding Of Control Design And Control Operating Effectiveness" (44\% Of Respondents),

- $\quad$ "Internal Audit Able To Perform More Traditional Audits (Operational And Non Financial Reporting Related)" (43\% Of Respondents), And

- $\quad$ "Increased effectiveness and efficiency of operations" $\left(42 \%\right.$ of respondents) ${ }^{10}$

It appears that as time progresses and the learning curve associated with the initial implementation and compliance decreases, many executives have realized the benefits derived from compliance with the Act, thus eliminating the debate over whether or not the costs outweighed the associated benefits.

\section{WHY WOULD PRIVATE COMPANIES VOLUNTARILY EMPLOY SOX-LIKE PROCEDURES?}

While the 2010 and 2012 surveys conducted by Protiviti provided some hope that the compliance costs associated with SOX provisions are not valueless and with time eventually decrease (as a result of the benefits many companies seek to derive from compliance in their fourth compliance year or later), many would still be alarmed by the enormous price tag associated with initial compliance.

AMR Research noted that companies incurred approximately $\$ 6$ billion a year in compliance costs. Additionally, Foley \& Lardner's research revealed that the costs associated with being a publicly traded company increased by $233 \% .{ }^{11}$ Even though these costs decrease over time, one might wonder why private companies (henceforth referred to as "private companies" or "nonpublic entities") would voluntarily employ SOX-like procedures and policies, especially when they are not required to do so.

Since enactment, many surveys have been conducted to view aspects of compliance with the Act. Based on the results of those surveys, the consensus is that compliance with the Act allows companies to realize additional benefits, particularly in later years of compliance. To summarize the research conducted and results of the surveys, companies that employ SOX procedures and policies and are deemed compliant have identified associated benefits of compliance:

- $\quad$ Reducing non-value added work ${ }^{12}$

- $\quad$ Overall increase in the effectiveness and efficiency of processes and operations and ${ }^{13}$

- Greater understanding and knowledge of control objectives and design. ${ }^{14}$

\footnotetext{
${ }^{9}$ Ibid

${ }^{10}$ Christensen, B., \& DeLoach, J. (2012). Sarbanes-Oxley: What do financial executives really think? Financial Executive, $28(5), 58-61$.

${ }^{11}$ Bradford, M., Taylor, E., \& Brazel, J. (2010). Beyond compliance: The value of SOX. Strategic Finance, 9(11), 48-53.

${ }^{12}$ Ibid

${ }^{13}$ (2010). New research from Protiviti finds majority of executives experienced with Sarbanes-Oxley compliance believe benefits outweigh the costs; new sox survey uncovers spending trends, attitudes, outlooks and more. PR Newswire.

${ }^{14} \mathrm{Ibid}$
} 
The results of the 2010 study conducted by Bradford, Taylor \& Brazel, with the support of the Institute of Management Accountants' (IMA) Foundation for Applied Research, confirms this conclusion. Bradford, Taylor \& Brazel (2010) have also identified the following as additional benefits of compliance:

- $\quad$ Companies that are SOX compliant have realized and achieved strategic goals

- $\quad$ SOX compliance has led to effective and efficient analysis of performance

- Companies have achieved comprehensive improvements in performance by standardizing and upgrading processes

- Duplicative processes have been identified and eliminated, increasing efficiency and effectiveness

- Transparency of reported information has increased

- Financial reporting has improved as a result of stronger, effective and efficient internal controls over financial reporting

- Increased improvement in the efficiency of both internal and external audits, thereby decreasing audit costs - $\quad$ Automating manual controls increasing time efficiency ${ }^{15}$

Managers who have shifted from a negative compliance perspective of SOX to a positive one have been able to realize the aforementioned benefits. In their study, the IMA sent 2,284 email surveys to members who held accounting related titles in a variety of industries including manufacturing, retail, wholesale distribution, telecommunications, government, not for profit, healthcare, financial services, and construction. The purpose of the survey was to examine the benefits both public and nonpublic entities experienced through improvement of their internal controls. Of the 273 respondents, 124 (45\%) were from public firms and $149(55 \%)$ were from nonpublic entities. In an effort to determine the value-added SOX 404 outcomes for public entities and improvements attributable to the enhancement of internal controls for nonpublic entities, the survey measured variables including efficiency of internal and external audit processes, reduction in non-value added work, overall improvement of operations, and the improvement of financial accounting processes. ${ }^{16}$

Bradford, Taylor and Brazel (2010) also reported that both public and private entities experienced improvements in their overall processes, the responsibilities of their employees expanded, duplicated activities were identified and eliminated, and manual controls were automated. ${ }^{17}$

While the benefits seem to be reason enough for private companies to employ SOX-like policies and procedures, there are additional factors that may further convince management to implement such procedures. State and federal agencies have taken notice of the overall improvements associated with SOX compliance for public entities and internal control improvements for nonpublic entities. Therefore, in response to such factors many states and federal agencies have begun or considered implementing SOX-like legislation for private entities.

A number of states have also adopted or are considering imposing SOX-like provisions to private companies that operate within their jurisdiction. For example, in 2006 and 2007, the Commonwealth of Virginia and the state of North Carolina passed SOX-like legislation. In 2006, the Department of Accounts of the Commonwealth of Virginia issued the Comptroller's Directive No. 1-07, Agency Risk Management and Internal Control Standards (ARMICS). According to the directive, private companies would be required to certify to the Office of the Comptroller as well as the Auditor of Public Accounts that they have established, maintained and conducted an evaluation of their company's internal control framework. Annual certifications issued to private companies will be contingent upon compliance with this directive. ${ }^{18}$

Federal agencies have also considered imposing SOX-like provisions on nonpublic entities. For example, the Federal Deposit Insurance Corporation considered encouraging private banks with less than $\$ 500$ million in total assets to comply with a number of SOX-like guidelines (the guidelines will be mandatory for private banks that have more than $\$ 500$ million in total assets). Additionally, any private company that contracts with governmental

\footnotetext{
${ }^{15}$ Bradford, M., Taylor, E., \& Brazel, J. (2010). Beyond compliance: The value of SOX. Strategic Finance, 9(11), 48-53

${ }^{16} \mathrm{Ibid}$

${ }^{17}$ Ibid

${ }^{18}$ Ibid
} 
agencies will find that some form of SOX-like compliance will be required in order to obtain and/or retain a contractual relationship with governmental agencies. ${ }^{19}$

Dalton \& Dalton (2005) reported that even if private entities are not subject to the provisions of SOX, operate in a state that imposes compliance, or are not subject to Federal SOX-like regulations, there are multiple reasons why a private entity should consider becoming SOX compliant. These reasons include:

- Investors and underwriters will insist upon compliance prior to any IPO (initial public offering). Additionally, adopting SOX-like provisions will help in the initial public offering process.

- Insurance companies will request certified financial statements in order to establish coverage for directors and officers.

- $\quad$ Private companies that wish to raise capital from banks or private equity firms will be required to provide audited financial statements as well as assurances regarding corporate governance. ${ }^{20}$

Based upon these benefits, one can see why private entities might consider employing SOX-like policies and procedures. While initial compliance costs are significantly high, they have decreased over time, as evidenced by responses to the 2010 survey conducted by Protiviti, where respondents in their fourth compliance year or later reported, on average, a $50 \%$ reduction in compliance costs. Furthermore, $87 \%$ of respondents noted that compliance would provide numerous benefits (as shown above). When considering the associated benefits of compliance as well as the state/federal SOX-like legislation imposed on private entities, it is easy to see long-term compliance will provide private entities a competitive edge in their marketplace and respective industry. ${ }^{21}$

Overall, entities that possess a strong internal control system are more apt to quickly respond to risky events and turn such events into opportunities to further expand the effectiveness and efficiency of their organization. A strong internal control environment is essential for all entities, whether public or private. Ultimately, a strong internal control system provides a company with a competitive advantage to identify and build upon strengths as well as reduce weaknesses. Such practices will allow companies to realize the associated benefits with SOX compliance ${ }^{22}$.

\section{CONCLUSION}

Based upon the examination of how SOX compliance has progressed and its benefits public and nonpublic organizations have derived since the enactment of the 2002 legislation, it's hard to believe that the Act was once received with such negativity. The Act was implemented during a state of alarm for companies and auditors. As a result of the notable fraud scandals as well as corporate asset misappropriation, upper level management of public entities must focus on the potential ramifications of poor internal controls (i.e. non-compliance with Section 404 of the Act). Such concern led to the centralized focus of all controls that mitigated the smallest risks with little to no consideration as to the significance each risk posed to the company as a whole. A 'bottom up' approach resulted from such narrow focus. This approach led to the exorbitant initial compliance costs as well as the burdens many companies cited during the initial compliance phase. ${ }^{23}$

The research documented above illustrates that the benefits derived from compliance, have justified the increased costs and work. The increased compliance costs as well as the increase in time spent ensuring compliance with the Act paid off for companies, making the derived benefits of compliance outweigh the initial compliance costs. Christiensen and DeLoach (2012) report that with more than ten years of experience with compliance,

\footnotetext{
${ }^{19}$ Dalton, D. R., \& Dalton, C. M. (2005). Sarbanes-Oxley legislation and the private company: If not a marriage, then certainly an engagement. Journal of Business Strategy, 26(2), 7-8.

${ }^{20}$ Ibid

${ }^{21}$ New research from Protiviti finds majority of executives experienced with Sarbanes-Oxley compliance believe benefits outweigh the costs; new sox survey uncovers spending trends, attitudes, outlooks and more. PR Newswire.

${ }^{22}$ Jeffrey, C. (2008). Internal control at private companies and nonprofits. CPA Journal, 78(9), 52-54.

${ }^{23}$ Ibid
} 
companies have been able to take it a step further to develop "lessons learned for improving Section 404 compliance." ${ }^{24}$ These ten lessons include:

(1) "Deploy a top-down approach to focus on what's really important."

(2) "Consider qualitative and quantitative factors to implement a truly risk-based approach in selecting what to evaluate and document."

(3) "Incorporate prior controls experience into the assessment process."

(4) "Apply a balanced approach of self-assessment, entity-level monitoring, process-level monitoring and detailed testing techniques to improve reliability of results and ongoing transparency."

(5) "Allow sufficient time in the process for remediating control deficiencies and retesting improvements."

(6) "Maximize the quality of communications with the external auditor throughout the process."

(7) "Treat the compliance effort as a significant project requiring project management discipline."

(8) "Engage unit managers and process owners in the compliance process and hold them accountable."

(9) "Improve operational effectiveness and efficiency of upstream financial reporting processes."

(10) "Automatic controls to increase the cost-effectiveness of the controls portfolio." 25

Moran (2013) notes that it seems that over the last decade, companies that have been able to realize the benefits associated with SOX compliance are those that have followed the intent of the legislation in the way they operate and conduct business on a day to day basis. In doing so, companies have conducted compliance efforts in a more effective and efficient manner ${ }^{26}$.

Since its implementation, the Act has made it clear through the actions of Congress, improvement in the marketplace as well as the boost in investor confidence that a strong, effective and efficient internal control system and environment are essential to the success and viability of any organization, whether it is public or private. ${ }^{27}$ As a result of the benefits and improvements associated with the Sarbanes Oxley Act of 2002, it appears that the Act has far surpassed its initial intention, goals and expectations. The Act has forever changed the profession as well as the framework many public and nonpublic entities operate under.

\section{ACKNOWLEDGEMENTS}

This research was funded in part by a summer research grant from Hofstra University.

\section{AUTHOR INFORMATION}

Anthony Basile, Ph.D., CPA, CVA, CFE, is an Associate Professor in the Frank G. Zarb School of Business at Hofstra University. For the past 25 years, Dr. Basile has been teaching undergraduate and graduate courses in forensic accounting, fraud, auditing and taxation. He holds a B.B.A. in Accounting from Hofstra University, an M.S. in Taxation from Long Island University and a Ph.D. in Business Education from New York University. Dr. Basile's doctoral dissertation won a national research award as the Most Outstanding Dissertation in Business Education in 2001. Dr. Basile was also the technical writer for SSVS\#1, the one and only Business Valuation pronouncement issued by the American Institute of Certified Public Accountants. Dr. Basile's other research has been published in accounting, taxation, education and legal journals. E-mail: abasile@basilecpa.com (corresponding author)

Sheila A. Handy, Ph.D., CPA, is a Professor and the Chair of the Department of Business Management at East Stroudsburg University. Dr. Handy teaches Financial and Tax Accounting classes. She holds a B.B.A. and an M.B.A. in Accounting from Hofstra University and a Ph.D. in Business Education from New York University. Dr. Handy has nearly 30 years of university teaching experience and began her career in the tax department of Arthur Andersen and Company.

\footnotetext{
${ }^{24}$ Christensen, B., \& DeLoach, J. (2012). Sarbanes-oxley: What do financial executives really think? Financial Executive, 28(5), 58-61.

${ }^{25}$ Moran, P. (2013). Executive perspective: What we've learned from sarbanes-oxley. Pennsylvania CPA Journal, 84(2), 32-35

${ }^{26}$ Moran, P. (2013). Executive perspective: What we've learned from sarbanes-oxley. Pennsylvania CPA Journal, 84(2), 32-35.

${ }^{27}$ Jeffrey, C. (2008). Internal control at private companies and nonprofits. CPA Journal, 78(9), 52-54.
} 
Felisha Fret is a recent graduate of Hofstra University, currently working as an auditor at a medium- sized accounting firm in Long Island, NY. She holds a B.B.A. in Accounting and an M.S. in Taxation from Hofstra University. Felisha has six years of experience in public accounting and began her career at Deloitte \& Touche, LLP.

\section{REFERENCES}

Bradford, M., Taylor, E., \& Brazel, J. (2010). Beyond compliance: The value of sox. Strategic Finance, 9(11), 4853.

Bradford, M. \& Brazel, J. (2007). Flirting with SOX 404: Are private companies interested in a relationship?. Strategic Finance, 89(3), 48-53.

Christensen, B., \& DeLoach, J. (2012). Sarbanes-oxley: What do financial executives really think? Financial Executive, 28(5), 58-61.

Cozad, M.A. (2005). Top 5 best practices for small companies. Strategic Finance, 87(4), 42-46.

Dalton, D. R., \& Dalton, C. M. (2005). Sarbanes-oxley legislation and the private company: If not a marriage, then certainly an engagement. Journal of Business Strategy, 26(2), 7-8.

(2012). Firms highlight reporting benefits of sarbanes-oxley. Financial Management. ("Firms highlight reporting," 2012)

Jeffrey, C. (2008). Internal control at private companies and nonprofits. CPA Journal, 78(9), 52-54.

Moran, P. (2013). Executive perspective: What we've learned from sarbanes-oxley. Pennsylvania CPA Journal, 84(2), 32-35.

(2010). New research from protiviti finds majority of executives experienced with sarbanes-oxley compliance believe benefits outweigh the costs; new sox survey uncovers spending trends, attitudes, outlooks and more. PR Newswire. 